Bond University

Research Repository

\title{
Emotional intelligence, peer attachment and career indecision
}

Bartrum, Dee; Hicks, Richard; Alexander, Victoria

Published in:

Proceedings of the 3rd Annual International Conference on Cognitive and Behavioral Psychology

Licence:

CC BY-NC

Link to output in Bond University research repository.

Recommended citation(APA):

Bartrum, D., Hicks, R., \& Alexander, V. (2014). Emotional intelligence, peer attachment and career indecision. In Proceedings of the 3rd Annual International Conference on Cognitive and Behavioral Psychology (pp. 145-149). (Annual International Conference on Cognitive \& Behavioral Psychology). Global Science and Technology Forum.

\footnotetext{
General rights

Copyright and moral rights for the publications made accessible in the public portal are retained by the authors and/or other copyright owners and it is a condition of accessing publications that users recognise and abide by the legal requirements associated with these rights.

For more information, or if you believe that this document breaches copyright, please contact the Bond University research repository coordinator.
} 


\section{Emotional Intelligence, Peer Attachment and Career Indecision}

\author{
Dee Bartrum \\ NSW Health \\ Richard Hicks \\ Bond University \\ rhicks@staff.bond.edu.au
}

\author{
Victoria Alexander \\ Bond University
}

\begin{abstract}
Effective career decision making has been associated with parental attachment, and emotional intelligence has also been seen to be linked with recollected parental support styles. However, until recently there has been little research on how emotional intelligence (as a personal trait) might be linked with career decision making and with the levels of currently perceived (peer) attachments. Emotional intelligence is receiving increased attention in relation to major life decisions including career decisions but few studies have identified how trait emotional intelligence facets are related to career certainty and career indecision, nor examined the links with peer attachment variables (trust, communication, alienation). This paper reports a study of 142 university students who completed the full version of the Trait Emotional Intelligence Questionnaire (TEIQue), the peer attachment section of the Inventory of Parental and Peer Attachment (IPPA) and the Career Decision Scale (CDS). Significant inter-correlations as anticipated were found between a number of the scales of the TEIQue, the IPPA, and the CDS. In regression equations career indecision was predicted by the selfcontrol and emotionality domains of the TEIQue and by the trust and alienation scales of the IPPA (but not the communication scale). When the subscales of the two domains were related to career indecision, only impulsivity, emotion expression and relationships were significant contributors. These three EI subscales along with Alienation from the peer attachment scales all contributed significantly to career indecision. Implications for theory and practice are drawn.
\end{abstract}

Keywords- Trait emotional intelligence; Peer Attachment, Career indecision

\section{INTRODUCTION}

\section{A. Context and Rationale for Study}

Career indecision is common during adolescence as young people aim to find their way in school and university (cf., Tokar, Withrow, Hall, \&Miradi, 2003), and school curricula and counsellors aim to deal with the problems faced (Brown, 2007). Career indecision is known to be correlated with cognitive inability, depression, anxiety, stress, and personality and emotions generally (Campagna \& Curtis, 2007; Creed, Patton, \& Bartrum, 2004; Meldahl \& Muchinsky, 1997; Osipow \& Walsh, 1995; Page, Bruch, \& Haase, 2008). Most of these studies emphasise intrapersonal factors and few give attention to interpersonal factors (interpsychic and social factors). These few have tended to examine areas such as social attachments (peer and parental) in relation to career decisionmaking (e.g., Armsden \& Greenberg, 1987; Cenkseven-Onder, Kirdok, \& Isik, 2010, Guerra \& BraungartRicker, 1999; Wolfe \& Betz, 2004; Wright \& Perrone, 2008) and emotions in relation to career decision making (cf., Gati et al., 2011). Emotional intelligence has been examined also in relation to its correlates such as in relation to attachment styles (Hamarta, Deniz, \& Saltali, 2009), psychological well-being and emotion-related decisions (Mavroveli, Petrides, Sangareau, \& Furnham, 2009; Sevdalis, Petrides, \& Harvey, 2007; Soka \& Gati, 2007) and vocational development (cf., Petrides \& Furnham, 2006) . However, little attention has been given to how emotional intelligence and its facets may be related to career certainty and career indecision. This current paper examines this aspect and also examines the perceptions respondents had of the quality of their current peer attachments (in terms of trust, alienation, and communication) in relation to career indecision, across a sample of 142 Australian university students.

Career certainty involves decision ability and commitment to a career decision, whereas career indecision involves inability to decide and commit (Guay, Senecal, Gauthier, \& Fernet, 2003). Career certainty and indecision appear to be related identity achievement and identity diffusion in Marcia's stages of career development (cf., Marcia, 1993). Peers influence teenagers and young adults more and more as they achieve adult status and move away from parental influence. There are no studies identified by the authors that have examined the extent to which facets of peer attachment such as communication, trust and alienation are related to career certainty and career indecision and few that examine how emotional intelligence and peer influences may interact together to contribute to career certainty and indecision. This paper reports on these aspects.

\section{B. $\quad$ Career decision making}

Career commitment requires stability in choice, understanding of one's own aptitudes, values, and personality in relation to the world of work, and is associated with resilience and 
resourcefulness (Alexander, Hicks, \& Bartrum, 2011; Brown, 2007; Page, Bruch, \& Haase, 2008).

The template is used to format your paper and style the text. All margins, column widths, line spaces, and text fonts are prescribed; please do not alter them. You may note peculiarities. For example, the head margin in this template measures proportionately more than is customary. This measurement and others are deliberate, using specifications that anticipate your paper as one part of the entire proceedings, and not as an independent document. Please do not revise any of the current designations.

\section{Peer attachment}

Vignoli, Croity-Belz, Chapland, Fillipis, and Garcia (2005) found that parental attachment, and parenting styles were related to career exploration and career satisfaction among adolescents as had been indicated in an earlier study by Blustein, Walbridge, Friedlander, and Palladino (1995), suggesting that the quality of the attachment relationship may facilitate vocational exploration due to the emotional support given by the parents. Guerra and Braungart-Rieker (1999) found that students who had a secure relationship with their parents were likely to have less career indecision and Felsman and Blustein (1999) and Wolfe and Betz (2004) cited peer attachment as a likely important factor in career decision making. Guay et al. (2003) found that the level of support from peers was positively related to making a career decision for both males and females, and was more important than parental influence. Could the same be true of peer attachments in relation to career certainty and career indecision?. These studies suggested that peer attachment may play a role in the ability to decide on a career choice. But emotional intelligence also has been implicated in the ability to make effective decisions about lfe. This aspect was also examined in our study and was the primary motivator for the project, since emotions may well underpin career decision making. What is emotional intelligence and what does research suggest in relation to decision making (and where available to career decision making)?

\section{Emotional intelligence}

There is a strong history in the field of the measurement of emotional intelligence, with two major thrusts evident. One emphasises EI as a skill or cognitive variable, the other emphasises EI as a trait or characteristic of an individual more akin to a personality measure (self-reported). The current paper gives attention to EI as a trait measure, and specifically to the questionnaire developed by Petrides and Furnham (2003) to measure the trait aspect- the Trait Emotional Intelligence Questionnaire (TEIQue). As Petrides, Pita, and Kokkinaki (2007) argue trait EI or "trait emotional selfefficacy" involves the interconnection and combination of a variety of emotional self-perceptions which can be integrated into higher order factors or domains (cf., Cooper \& Petrides, 2010). These lower level perceptions or facets are the fifteen subscale facets of the TEIQue (each part of one of the four higher level domains- see Method): adaptability, emotion regulation, impulsivity, self-motivation, empathy, assertiveness, emotion expression, relationships, social awareness, happiness, emotion perception, emotion management, self-esteem and stress management. Each of these has demonstrated high level psychometric properties and relationships with health and wellbeing correlates. Indeed the TEIQue has been used extensively in emotion-related studies such as psychological well-being and psychopathology (Ali, Amorim, \& Chamorro-Premuzic, 2009; Johnson, Batey, \& Holdsworth, 2009)), personal relationship satisfaction (Smith, Heaven, \& Ciarrochi, 2008); and neurological-biological studies (Vernon, Villani, Schermer, \& Petrides, 2008).

We decided to investigate these relationships on emotional intelligence, peer attachment and career decision making within the sample of Australian university students.

The current study therefore aimed to replicate and extend earlier studies on career indecision, specifically in emotional intelligence and perceived peer relationships as correlates and predictors of career indecision/ career decision making. Several hypotheses were raised for the study:

- H1: That Career Indecision scores would be significantly and negatively related to Trait Emotional Intelligence scores,

- H2: To examine the CI/EI relationship in more detail, it was further hypothesised that Career Indecision scores would be significantly predicted by the combination of each of the four domains of the TEIQue EI scale (Wellbeing, Self Control, Emotionality and Sociability),

- H3: That Career Indecision would be significantly predicted by the three subscales of the Inventory of Peer and Parental Attachment Scale (IPPA: Trust, Communication and Alienation)

- H4: That Career Indecision would be significantly predicted by a combination of the significantly related scales from the TEIQue and IPPA

\section{METHOD}

\section{E. Participants and Materials}

Participants were 150 university students who were at undergraduate level within a variety of degrees across the university. Most were psychology undergraduates who completed the research as part of their requirements for their undergraduate studies. All completed the questionnaires in the following three areas of the currently reported party of the study (along with a number of other questionnaires as part of a larger study, and a demographics questionnaire).

1) Emotional intelligence. Emotional intelligence was measured using the Trait Emotional Intelligence Questionnaire (TEIQue; Petrides \& Furnham, 2003), a 153-item questionnaire assessing fifteen comprehensive facets of EI that are formed into four main domains: Well-being, Self Control, 
Emotionality, and Sociability. As indicated above, the TEIQue has now been used extensively in research around the world and has been demonstrated to have excellent psychometrics (e.g., Cooper \& Petrides, 2010; Petrides, 2009). In our study Cronbach alpha coefficients were generally in the .70 to .85 range across the facets and domains.

2) Peer attachment. Peer attachment was measured using the peer attachment section of the Inventory of Parent and Peer Attachment (IPPA; Armsden \& Greenberg, 1987), involving 25 items across 3 subscales: Trust (10 items), Communication ( 8 items), and Alienation ( 7 items). A 5 point Likert response scale is used, ranging from (1) Always true or always, to (5) Almost never or never. Good psychometrics exist (e.g., Gullone \& Robinson, 2005) with reported Cronbach alphas from .69 to .87 for the Communication, Trust, and Alienation subscales. In our current sample, Cronbach's alpha coefficients ranged from .77 to .82 for the subscales.

3) Career Decision Scale. The Career Decision Scale (CDS; Osipow, 1987) is a 19-item scale assessing Career Indecision (16 items)- a measure of individuals inability to decide upon a career; and Career Certainty ( 2 items)- measure of individuals' level of certainty in having made a career decision. Adequate psychometrics have been found (e.g., Betz \& Voyten, 1997 reported an internal consistency of .89 for the Indecision Scale). In our sample we found .93 for Career Indecision and .69 for the Career Certainty scale.

\section{RESULTS}

\section{A. Preliminary Screening and Analyses}

Data were screened for missing values, outliers, and whether the usual statistical assumptions were met or needed attention. Of 150 respondent profile sheets, eight were deficient and were removed, leaving a total of 142 respondent profiles for consideration in the data analyses.

TABLE I.

SUMMARY OF THE REGRESSION ANALYSIS FOR CAREER INDECISION ENTERING EMOTIONAL INTELLIGENCE PREDICTOR VARIABLES

\begin{tabular}{ccccc}
\hline Variable & $\boldsymbol{B}$ & $\boldsymbol{S E} \boldsymbol{B}$ & $\boldsymbol{\beta}$ & $\boldsymbol{p}$ \\
\hline Well Being & -.05 & .04 & -.14 & .22 \\
Self Control & -.08 & .032 & -.22 & .01 \\
Emotionality & -.08 & .032 & -.29 & .01 \\
& & & & .95 \\
Sociability & -.00 & .032 & -.01 & \\
Total R & .32 & & & .00 \\
\hline
\end{tabular}

Hypothesis 1, that Career Indecision scores would be significantly predicted by the four domains of the TEIQue EI scale (Well-being, Self Control, Emotionality and Sociability) was partially supported. The results are shown in Table 1 . The results demonstrated that the four domain variables significantly accounted for $32 \%$ (Adjusted $R^{2}=.30$ ) of the variance, $F(4,137)=15.85, p<.001$ in Career Indecision. Inspection of the regression coefficients demonstrated that Self Control $(\beta=-.22, t=-.26 p<.01)$ and Emotionality $(\beta=-$ $.29, t=2.54, p<.01)$ were significant predictors of Career Indecision; whereas Well-being and Sociability were not significant predictors when the contributions from SelfControl and Emotionality were taken into account.

TABLE II.

SUMMARY OF THE MULTIPLE REGRESSION ANALYSIS FOR CAREER INDECISION ENTERING EMOTIONAL INTELLIGENCE SUBSCALES OF EMOTIONALITY AND SELF CONTROL VARIABLES.

\begin{tabular}{ccccc}
\hline Variable & $\boldsymbol{B}$ & $\boldsymbol{S E} \boldsymbol{B}$ & $\boldsymbol{\beta}$ & $\boldsymbol{p}$ \\
\hline Self Control: Emotion Regulation & -.08 & .13 & -.07 & .54 \\
Self Control: Stress Management & -.02 & .12 & -.01 & .90 \\
Self Control: Impulsivity (Low) & -.20 & .09 & -.21 & .02 \\
& & & & \\
Emotionality: Emotion Perception & -.01 & .12 & -.01 & .96 \\
& & & & \\
Emotionality: Emption Expression & -.19 & .08 & -.23 & .02 \\
Emotionality: Empathy & -.00 & .11 & -.00 & .98 \\
Emotionality: Relationships & -.24 & .02 & -23 & .96 \\
Total R & .33 & & & .00
\end{tabular}

The subscales that comprised of the significant domains of Self Control and Emotionality were then entered into a regression to see whether they would predict Career Indecision.

Hypothesis 2, that Career Indecision scores would be significantly predicted by the subscales found to be significant from the four domains of the TEIQue EI scale was partially supported. The results are shown in Table 2. The results demonstrated that the seven variables which made up the two domains significantly accounted for $34 \%$ (Adjusted $R^{2}=.30$ ) of the variance, $F(4,137)=9.73, p<.001$ in Career Indecision. Inspection of the regression coefficients demonstrated that Emotion Expression $(\beta=-23, t=-.2 .36, p<$ $.05)$, Impulsivity (Low) $(\beta=-.21, t=-2.36, p<.05)$ and Relationships $(\beta=-.23, t=2.34, p<.015$ were significant predictors of Career Indecision; whereas Emotion Regulation, Stress Management, Emption Perception and Empathy were not significant predictors when the contributions from Emotion Expression, Impulsivity (Low) and Relationships were taken into account.

TABLE III. SUMMARY OF THE MULTIPLE REGRESSION ANALYSIS FOR CAREER INDECISION ENTERING THE THREE INVENTORY OF PEER ATTACHMENT SUBSCALES AS PREDICTOR VARIABLES

\begin{tabular}{ccccc}
\hline Variable & $B$ & $S E B$ & $\beta$ & $p$ \\
\hline Trust & -.06 & .02 & -.2 .67 & .01 \\
Communication & .00 & .02 & .02 & .88
\end{tabular}


Alienation $\quad .16 \quad .02 \quad .52 \quad .00$

Total $\mathrm{R}^{2} \quad .26$

.00

Hypothesis 3, that Career Indecision would be significantly predicted by the three subscales of the Inventory of Peer and Parental Attachment Scale (Trust, Communication and Alienation)

The results are shown in Table 3 . The results demonstrated that the three subscales accounted for $26 \%$ (Adjusted $R^{2}=.25$ ) of the variance, $F(3,138)=16.41, p<.001$ in Career Indecision. Inspection of the regression coefficients demonstrated that Trust $(\beta=-.27 t=-.2 .67, p<.05)$ and Alienation $(\beta=.52, t=6.79, p<.00$ were significant predictors of Career Indecision; whereas Communication was not a significant predictor when the contributions from Trust and Alienation were taken into account.

TABLE IV.

SUMMARY OF THE MULTIPLE REGRESSION ANALYSIS FOR CAREER INDECISION ENTERING EMOTION EXPRESSION, IMPULSIVITY (LOW), RELATIONSHIPS AND ALIENATION AS PREDICTOR VARIABLES

\begin{tabular}{ccccc}
\hline Variable & $B$ & $S E B$ & $\beta$ & $p$ \\
\hline Emotion Expression & -.17 & .07 & -.20 & .01 \\
Impulsivity (Low) & -.17 & .08 & -.17 & .02 \\
Relationships & -.23 & .08 & -.23 & .02 \\
Alienation & .08 & .02 & .28 & .00 \\
Total $\mathrm{R}^{2}$ & .40 & & & .00
\end{tabular}

Hypothesis 4, that Career Indecision would be significantly predicted by the subscales which were found to be significant from the four domains, as well as Alienation from the Inventory of Peer and Parental Attachment Scale.

The results are shown in Table 4. The results demonstrated that the four variables accounted for $40 \%$ (Adjusted $R^{2}=.38$ ) of the variance, $F(4,137)=22.82, p<.001$ in Career Indecision. Inspection of the regression coefficients demonstrated that Emotion Expression $(\beta=-.20 t=-.2 .59, p<$ $.05)$, Impulsivity (Low) $(\beta=-.17 t=-2.23, p<.05)$, Relationships $(\beta=-.23 t=-.2 .78, p<.00)$ and Alienation $(\beta$ $=.28, t=3.92, p<.00$ were all significant predictors of Career Indecision.

\section{DISCUSSION}

The relationships among emotional intelligence, peer relationships and career indecision have been examined in this paper. In line with hypotheses 1 and 2, which were thus partially supported, it was noted that the self-control and emotionality domains of the TEIQue predicted career indecision (though the domains of well-being and sociability did not), and that of the self-control and emotionality domains it was the facets of impulsivity, emotion expression and relationships (of the seven facets) that predicted career indecision. There were no previous studies to compare, though in general it had been argued emotional intelligence was related to general decision making efficacy (e.g., Betz \& Voysten, 1997; Gati et al., 2011; Soka \& Gati, 2007). These specific links first of the domains (self-control and emotionality) and the facets will require further study. A limitation of our study which applies to each of the hypotheses is that it is constrained to a particular sample and that the numbers are relatively low (though similar to many reported university student studies).

The next hypothesis, that there would be a relationship between the peer relationship subscales of trust communication and alienation was supported; however, it was the alienation and the trust scales that contributed to predicting career indecision and not the communication scale. This finding is not unexpected in that how young people relate (trustworthy/rejecting) is likely linked to earlier parental attachments; the literature has demonstrated in many studies that parental or combined parental and peer relationships affect life style, moods (depression, anxiety) and self-efficacy generally (e.g., Alexander, Hicks, \& Bartrum, 2010; Armsden $\&$ Greenberg, 1987). However, of interest was that the trust and alienation aspects were highly negatively related, with alienation being the major contributor to career indecision. Not being able to build and maintain positive relationships with peers clearly has a strong negative affect on many parts of life, not only career decision making. Because of the strong overlap alienation was chosen as the main peer relationship variable to be included in the final hypothesis- that significant facets from the TEIQue and the IPPA would predict career indecision.

This final hypothesis was supported, with all four facets significantly working together to predict career indecision. Being impulsive, not being able to identify or express emotions, having poor relationships with others and being alienated together were powerful predictors of career indecision.

The implications for theory are that trait emotional intelligence facets as well as peer relationships combine and indicate the associations present in those who may be having difficulties in career decision making. The implications for practice are that such relationships cannot be ignored. Before individuals can commit to a career decision perhaps they must first be helped to develop their own personal relationship and emotional skills and approaches.

\section{REFERENCES}

[1] Alexander, V., Hicks, R.E., \& Bartrum, D. (2011). Resilience and resourcefulness in dealing with uncertainty in life commitment: Career choice as a case example. In M.J. Celinski \& K.M. Gow (Eds.). Continuity versus creative response to challenge: The primacy of resilience and resourcefulness in life and therapy). New York: Nova Science 
[2] Ali, F., Amorim, I. S., \& Chamorro-Premuzic, T. (2009). Empathy deficits and trait emotional intelligence in psychopathy and Machiavellianism. Personality and Individual Differences, 47, 758-762.

[3] Armsden, G.C., \& Greenberg, M.T. (1987). The inventory of Parent and Peer Attachment:Individual differences and their relationship to psychological well-being in adolescence. Journal of Youth and Adolescence, 16, 427-453. Retrieved from http://www.springerlink.com.ezproxy.bond.edu.au/content/104945/

[4] Betz, N.E., \& Voysten, K.K. (1997). Efficacy and outcome expectations influence career exploration and decidedness. The Career Development Quarterly, 46, 179-189. Retrieved from http:/www.counseling.org/publications/journals.htm

[5] Blustein, D.L., Walbridge, M.M., Friedlander, M.L., \& Palladino, D.E. (1991). Contributions of psychological separation and parental attachment to the career development process. Journal of Counseling Psychology, 38, 39-50. Retrieved from http:/www.apa.org/pubs/journals/cou/index.aspx

[6] Brown, D. (2007). Career information, career counselling, and career development ( $9^{\text {th }}$ Ed.). Boston: Pearson/Allyn \& Bacon

[7] Campagna, C. G., \& Curtis, G. J. (2007). So worried I don't know what to be: Anxiety is associated with increased career indecision and reduced career certainty. Australian Journal of Guidance and Counselling, 17, 91-96. DOI: 10.1375/ajgc.17.1.91

[8] Cenkseven-Onder, F., Kirdok, O., \& Isik, E. (2010). High school students' career decision making pattern across parenting styles and parental attachment levels. Journal of Research in Educational Psychology, 8(1), 263-280. Retrieved from http://www apa.org/pubs/journals/edu/index.aspx

[9] Cooper, A. \& Petrides, K. V. (2010). A psychometric analysis of the Trait Emotional Intelligence Questionnaire-Short Form (TEIQue-SF) using Item Response Theory. Journal of Personality Assessment, 92, 449-457.

[10] Creed, P.A., Patton, W., \& Bartrum, D. (2004). Internal and external barriers, cognitive style, and the career development variables of focus and indecision. Journal of Career Development, 30, 277-294

[11] Creed, P., Prideaux, L.A., \& Patton, W. (2005). Antecedents and consequences of career decisional states in adolescence. Journal of Vocational Behavior, 67, 397-412. doi:10.1016/j.jvb.2004.08.008

[12] Felsman, D.E., \& Blustein, D.L. (1999). The role of peer relatedness in late adolescent career development. Journal of Vocational Behaviour, 54, 279-295. doi:10.1006/jvbe.1998.1664

[13] Gati, I., Gadassi, R., Saka, N., Hadadi, Y., Ansenberg, N., Friedman, R., \& Asulin-Peretz, L. (2011). Emotional and personality-related aspects of career decision-making difficulties: Facets of career indecisiveness. Journal of Career Assessment, 19, 3-20. DOI: $10.1177 / 1069072710382525$.

[14] Guay, F., Senecal, C., Gauthier, L. \& Fernet, C. (2003). Predicting career indecision: A self determination theory perspective. Journal of Counseling Psychology, 50, 165-177. Retrieved from http://www.apa.org/pubs/journals/cou/index.aspx

[15] Guerra, A., \& Braungart-Ricker, J.M. (1999). Predicting career indecision in college students: The roles of identity formation and parental relationship factors. Career Development Quarterly, 47, 255266.

Retrieved

from http:/www, counseling, org/publications/journals. htm

[16] Gullone, E., \& Robinson, K. (2005). The Inventory of Parental and Peer Attachment Revised (IPPA-R) for children: A psychometric investigation. Clinical Psychology and Psychotherapy, 12, 67-79. doi: 10.1002/cpp.433

[17] Hamarta, E., Deniz, M., \& Saltali, N. (2009). Attachment styles as a predictor of emotional intelligence. Educational Sciences: Theory \& Practice, 9, 213-229

[18] Johnson, S. J., Batey, M., \& Holdsworth, L. (2009). Personality and health: The mediating role of Trait Emotional Intelligence and Work Locus of Control. Personality and Individual Differences, 47, 470-475
[19] Marcia, J. E. (1993). The ego identity status approach to ego identity. In J. E. Marcia, A. S. Waterman, D. R. Matteson, S. L. Archer, \& J. L. Orlofsky (Eds.), Ego identity: A handbook for psychosocial research (pp. 1-21). New York: Springer-Verlag

[20] Mavroveli, S., Petrides, K.V., Sangareau, Y., \& Furnham, A. (2009) . Exploring the relationships between trait emotional intelligence and objective socio-emotional outcomes in childhood. British Journal of Educational Psychology, 79, 259-272

[21] Meldahl, J.M., \& Muchinsky, P.M. (1997). The neurotic dimension of vocational indecision: Gender compatibility? Journal of Career Assessment, 5, 317-331. doi: 10.1177/106907279700500305

[22] Osipow, S. H. (1987). Career Decision Scale manual. Odessa, FL: Psychological Assessment Resources.

[23] Page, J., Bruch, M.A., \& Haase, R.F. (2008). Role of perfectionism and Five-Factor model traits in career indecision. Personality and Individual Differences , 45, 811-815

[24] Petrides, K. V. (2009). Technical manual for the Trait Emotional Intelligence Questionnaires (TEIQue). London: London Psychometric Laboratory

[25] Petrides, K. V., \& Furnham, A. (2003). Trait emotional intelligence: Behavioural validation in two studies of emotion recognition and reactivity to mood induction. European Journal of Personality, 17, 3957.

[26] Petrides, K. V. \& Furnham, A. (2006). The role of trait emotional intelligence in a gender-specific model of organizational variables. Journal of Applied Social Psychology, 36, 552-569.

[27] Petrides, K. V., Pita, R., \& Kokkinaki, F. (2007). The location of trait emotional intelligence in personality factor space. British Journal of Psychology, 98, 273-289.

[28] Sevdalis, N., Petrides, K. V., \& Harvey, N. (2007). Trait emotional intelligence and decision-related emotions. Personality and Individual Differences, 42, 1347-1358.

[29] Smith, L., Heaven, P. C. L., \& Ciarrochi, J. (2008). Trait emotional intelligence, conflict communication patterns, and relationship satisfaction. Personality and Individual Differences, 44, 1314-1325.

[30] Soka, N., \& Gati, I. (2007). Emotional and personality-related aspects of persistent career decision-making difficulties. Journal of Vocational Behavior, 71, 340-358. doi: 10.1016/j.jvb/2007.08.003

[31] Tokar, D.M., Withrow, J.R., Hall, R.J., \& Moradi, B. (2003). Psychological separation, attachment security, vocational self-concept crystallization and career indecision: A structural equation analysis. Journal of Consulting Psychology, 50, 3-19. Retrieved from http:/www.apa.org/pubs/journals/ccp/index.aspx

[32] Vernon, P. A., Villani, V. C., Schermer, J. A., \& Petrides, K. V. (2008) Phenotypic and genetic associations between the Big Five and trait emotional intelligence. Twin Research and Human Genetics, 11, 524530

[33] Vignoli, E., Croity-Belz, S., Chapeland, V., Fillipos, A.D. \& Garcia, M. (2005). Career exploration in adolescents: The role of anxiety, attachment and parenting style. Journal of Vocational Behavior, 67, 153168. doi: $10.1016 /$ i.j.jv. 2004.08 .006

[34] Wolfe, J.B., \& Betz, N.E. (2004). The relationship of attachment variables to career decision making self-efficacy and fear of commitment. The Career Development Quarterly, 52, 363-369. Retrieved from http://www.counseling.org/publications/journals.htm

[35] Wright, S.L., \& Perrone, K.M. (2008). The impact of attachment on career-related variables: A review of the literature and proposed theoretical framework to guide future research. Journal of Career Development, 35, 87-106. doi: 10.1177/0894845308325643 